\begin{tabular}{|l|l|l||}
\hline \multicolumn{2}{|c|}{ PublisherInfo } \\
\hline \hline PublisherName & $:$ & BioMed Central \\
\hline \hline PublisherLocation & $:$ & London \\
\hline \hline PublisherImprintName & $:$ & BioMed Central \\
\hline \hline
\end{tabular}

\title{
Haematopoietic stem cells
}

\begin{tabular}{|l|l|l||}
\hline \multicolumn{2}{|c|}{ ArticleInfo } \\
\hline \hline ArticleID & $:$ & 4683 \\
\hline \hline ArticleDOI & $:$ & $10.1186 /$ gb-spotlight-20030122-01 \\
\hline \hline ArticleCitationID & $:$ & spotlight-20030122-01 \\
\hline \hline ArticleSequenceNumber & $:$ & 35 \\
\hline \hline ArticleCategory & $:$ & Research news \\
\hline ArticleFirstPage & $:$ & 1 \\
\hline \hline ArticleLastPage & $:$ & 2 \\
\hline \hline & & RegistrationDate : 2003-1-22 \\
\hline ArticleHistory & $:$ & OnlineDate \\
\hline ArticleCopyright & $:$ & BioMed Central Ltd2003-1-22 \\
\hline \hline ArticleGrants & $:$ & \\
\hline \hline ArticleContext & $:$ & 130594411 \\
\hline \hline
\end{tabular}




\section{Jonathan B Weitzman}

Email: jonathanweitzman@hotmail.com

The transcription factor encoded by the stem cell leukemia SCL/tal-1 gene is essential for the embryonic development of haematopoietic stem cells (HSC). In an Advanced Online Publication in Nature Mikkola et al. describe analysis of mice with a conditional deletion of the SCL/tal-1 gene, generated to assess the factor's role in adult haematopoiesis (Nature 19 January 2003, doi;10.1038/ nature01345). Mice containing a loxP-flanked $S C L / t$ al-1 allele were bred with the mxCre strain in which Cre protein expression can be induced by polyI-polyC. Deletion of the $S C L / t a l-1$ gene in adult mice did not affect the differentiation or the maintenance of myeloid or lymphoid lineages. Bone-marrow transplantation experiments demonstrated that $S C L /$ tal-1 gene deletion did not affect contribution to all haematopoietic organs. The authors conclude that "loss of $S C L / t a l-1$ does not seem to impair considerably HSC properties, including engraftment, self-renewal and multipotency." These results suggest that transcription factors required for HSC genesis (such as $S C L / t a l-1$ ) may differ from those required for long-term repopulation and multipotency in adults.

\section{References}

1. Absence of blood formation in mice lacking the T-cell leukaemia oncoprotein tal-1/SCL.

2. Nature, [http://www.nature.com] 